\title{
JESZCZE O PODSTAWACH ETYKI SŁOWA W KOMUNIKACJI LITERACKIEJ
}

Mówiąc o podstawach etyki słowa, można mieć na myśli następujące zjawiska:

1. wstępne założenia, których przyjęcie jest konieczne dla uprawomocnienia etycznej oceny komunikacji, stanowiące teoretyczny fundament tej koncepcji;

2. normy etyczne stosowane w odniesieniu do wypowiedzi i ich uzasadnienie;

3. sposoby postępowania z konkretnymi wypowiedziami, reguły, według których są one oceniane.

Wszystkie wymienione zagadnienia bywają nazywane „podstawami” etyki słowa. Dotyczą one komunikacji jako takiej czy - lepiej - każdego rodzaju komunikacji, także niewerbalnej. W niniejszym artykule postaram się zarysować te problemy w odniesieniu do komunikacji literackiej, która stanowi główny przedmiot mojego zainteresowania ${ }^{1}$.

\section{PODSTAWY TEORETYCZNE}

Fundamentem etycznej oceny komunikacji jest performatywne ujęcie tej ostatniej, zbudowane na przekonaniu, że mówienie to nie tylko konstruowanie

Dr hab. ANNA KoZŁowsKA - Zakład Badań nad Językiem Autorów, Instytut Językoznawstwa UKSW; adres do korespondencji: Uniwersytet Kardynała Stefana Wyszyńskiego, ul. Dewajtis 5, 01-815 Warszawa; e-mail: a.kozlowska@uksw.edu.pl

${ }^{1}$ Tezy prezentowane w niniejszym tekście rozwijają i uściślają propozycje zawarte w pracy: A. KozŁowsKA, Etyczny wymiar komunikacji literackiej w perspektywie jezykoznawstwa, w: Ku rzeczom niebtahym, red. J. Chojak, Z. Zaron, Warszawa: BEL Studio 2018, s. 49-59. 
tekstu czy przekazywanie informacji, ale (współ)działanie. Tylko takie spojrzenie na komunikację, zaproponowane przez Johna L. Austina i Paula Grice'a i rozwijane w ramach różnych teorii pragmatycznych, uprawomocnia jej ocenę w kategoriach dobra/zła, której mogą przecież podlegać jedynie czyny, a nie elementy systemu języka czy teksty rozumiane jako wytwory mówienia. Dlatego właśnie możliwość rozpatrywania komunikacji w perspektywie etycznej nie pojawia się w obrębie tych teorii języka, które koncentrują się np. na opisie jego struktury czy wytworów ${ }^{2}$, wyłania się natomiast w myśleniu akcentującym jego wymiar zdarzeniowy oraz interakcyjny:

[...] język jest potężnym narzędziem używanym w kontaktach międzyludzkich. Używanie go może być oceniane w kategoriach etycznych tak samo, jak wszelkie inne działania podejmowane przez ludzi, a mające konsekwencje dla innych osób czy zbiorowości³ ${ }^{3}$.

Ze wskazanego założenia wynika, że przedmiotem waloryzacji moralnej jest nie tylko sam tekst jako ,produkt” użycia systemu języka, efekt zastosowania określonych reguł, ale cały akt mowy. Tekst stanowi tylko jeden z komponentów całej sytuacji komunikacyjnej, a w jej ostatecznej ocenie kluczową rolę odgrywają również inne elementy, takie jak np. intencja nadawcy czy skutki.

Przyjęcie performatywnej koncepcji komunikacji jest koniecznym warunkiem uprawomocnienia jej oceny etycznej, ale nie warunkiem wystarczającym. U podstaw etyki słowa leżą jeszcze inne założenia, związane zarówno z samą koncepcją języka, jak i z myśleniem o moralnym wymiarze czynów ludzkich w ogóle. Te pierwsze sformułowała explicite Jadwiga Puzynina:

Żeby uznać kłamstwo (szczególnie w formie zakłamania) za antywartość związaną z językiem, trzeba [...], po pierwsze, uważać język za narzędzie nie tylko mowy, ale i myśli, a więc wewnętrznego świata człowieka, po drugie, uznać język za wartość autoteliczną (co często podkreśla w swoich pracach np. prof. Markowski), za niezwykły, zobowiązujący dar - dla jednych - dar Boga, dla innych - natury,

${ }^{2}$ Przykładem może być artykuł Bogdana Walczaka Aksjologia a językoznawstwo, w: Wartości $i$ wartościowanie $w$ badaniach nad językiem, red. M. Karwatowska, A. Siwiec, Chełm: Wydawnictwo Perfekta info 2012, s. 20-29, w którym ze względu na strukturalistyczne założenia zakwestionowane zostało miejsce etyki słowa $\mathrm{w}$ obrębie kultury języka, a nawet lingwistyki w ogóle.

${ }^{3}$ T. ZGóŁKA, Język wśród wartości, Poznań: Wydawnictwo Poznańskie 1988, s. 88. 
dar, bez którego nie istniałaby np. nauka, a wraz z nią i cały postęp techniczny, nie istniałaby medycyna, literatura, wraz z całą myślą humanistyczną i filozoficznąa ${ }^{4}$.

Powyższy fragment, pochodzący z polemiki badaczki ze wspomnianym już artykułem Bogdana Walczaka, dotyczy wprawdzie kwestii kłamstwa, ale niewątpliwie można go odnieść także do wszelkich innych szczegółowych problemów etyki mowy, jak również do możliwości etycznej oceny komunikacji w ogóle.

Trzy wymienione już tezy dotyczące języka i komunikacji - czyli przyjęcie performatywnej natury komunikacji, uznanie języka za narzędzie poznania oraz dostrzeżenie w nim wartości autotelicznej - trzeba jeszcze uzupełnić o założenia przyjmowane dla wszelkich ludzkich czynów, które mają być oceniane z punktu widzenia moralnego, a mianowicie, że ich podmiot działa świadomie i dobrowolnie oraz że jest w stanie przewidzieć ewentualne konsekwencje swojego postępowania. Nie czujemy się przecież obrażeni czy zobligowani ani zachowaniami, ani też wypowiedziami bardzo małych dzieci (choć już dzieci można i trzeba zachęcać do respektowania zasad etycznych, w tym także etyki słowa), ludzi niepoczytalnych, będących pod wpływem środków odurzających oraz działających pod wyraźnym przymusem. Należałoby się w tym kontekście zastanowić nad sytuacją osób dysponujących bardzo ograniczonym kodem (w sensie nadanym temu określeniu przez Basila Bernsteina), np. używających wulgaryzmów jako podstawowego, czasem wręcz jedynego środka ekspresji albo nawykowo, bezrefleksyjnie stosujących środki wyrazu, które są nacechowane agresją ${ }^{5}$. Wszystkie akty mowy wykonywane przez takich użytkowników języka podlegają daleko posuniętym ograniczeniom: w zakresie umiejętności wyrażania myśli (czyli lokucji), świadomości celów (illokucji) i możliwości przewidywania skutków wypowiedzi (perlokucji). Ograniczenia te niekoniecznie znoszą czy zawieszają moc illokucyjną samego aktu, który może przecież nadal oddziaływać na świat przekonań odbiorcy/odbiorców, a tym samym w jakimś ogólnym sensie respektować bądź naruszać normy etyczne, ale łagodzą ocenę w konkretnych przypadkach bądź nawet całkowicie usprawiedliwiają zachowania mowne niezgodne $\mathrm{z}$ regułami, lecz zrozumiałe po rozpoznaniu uwarunkowań sytuacyjnych. Rzecz jasna, wiedza o tych ostatnich może również zaostrzać wymagania stawiane

\footnotetext{
4 J. PuZYnina, Dlaczego bronię kultury stowa?, „Poradnik Językowy” 2014, nr 5, s. 7-15.

${ }^{5} \mathrm{~W}$ odniesieniu do takich osób można chyba nawet mówić (choć zwykle się tego nie robi) o swoistym uzależnieniu od agresji, ponieważ tego rodzaju działania przebiegają poza kontrolą podmiotu.
} 
przed uczestnikami aktu mowy - od osób, którym przypisuje się wyjątkową sprawność językową czy większą niż przeciętna świadomość słowa, np. od pisarzy, naukowców, dziennikarzy, duchownych tradycyjnie oczekuje się większego poszanowania etycznych standardów komunikacji niż od użytkowników o przeciętnych kompetencjach i wiedzy.

Na marginesie warto zauważyć, że dobrowolność i świadomość to chyba jedyne w miarę powszechnie akceptowane cechy czynów uznawanych za dobre bądź złe. Jeśli idzie o zakres stosowania ocen moralnych, spotykamy bowiem bardzo rozbieżne stanowiska. Niektórzy etycy uważają, że wszystkie czyny ze względu na swoje ewentualne skutki są przynajmniej potencjalnie moralne/niemoralne; inni są skłonni dostrzegać wymiar moralny tylko w wybranych działaniach, np. mających znaczną wagę, piętnowanych przez prawo czy obyczaj albo związanych z relacjami, mających konkretnego adresata. Wydaje się, że podobną różnorodność prezentują postawy wobec komunikacji - można wśród nich odnaleźć zarówno przeświadczenie, że wszystkie akty mowy mają konsekwencje etyczne i w związku z tym wszystkie podlegaja tego rodzaju ocenie, jak i próby wyłączania z jej zasięgu np. wypowiedzi o niewielkim znaczeniu społecznym, prywatnych, pozbawionych wyraźnie określonego adresata itp. Pojawia się wreszcie - choć coraz rzadziej bywa formułowana explicite ${ }^{6}-$ myśl, że normy moralne zupełnie nie nadają się do waloryzowania czynności mowy, ufundowana na silnie zakorzenionym w naszej kulturze przekonaniu o zasadniczej odmienności, a nawet opozycyjności słów i czynów.

W świetle tego, o czym była mowa powyżej, wydaje się istotne, aby odróżniać obiektywną czy przynajmniej intersubiektywną wartość danego aktu mowy in potentia, jako elementu kompetencji komunikacyjnej (w przypadku niektórych aktów, np. donosu czy podlizywania się, waloryzacja moralna stanowi ich konstytutywny element), od oceny konkretnej sytuacji, w której ten akt się pojawił. Trzeba przy tym zauważyć, że także akty neutralne w sensie pierwszym, takie jak np. prośba czy powitanie, mają pewną potencję aksjologiczną i w użyciu, uwikłane w określoną konsytuację, mogą zyskać nacechowanie pozytywne bądź negatywne.

Mówiąc o etycznej ocenie konkretnej sytuacji, najczęściej odwołujemy się do kategorii odpowiedzialności moralnej. W przypadku komunikacji stosuje się zwykle formułę odpowiedzialność za stowo, która wprawdzie doskonale

\footnotetext{
${ }^{6}$ Być może wpłynęły na to kampanie społeczne uwrażliwiające na problem przemocy słownej, hejtu itp., a także stosunkowo liczne medialne doniesienia o tragicznych skutkach agresji komunikacyjnej, szczególnie wśród młodzieży.
} 
zdaje sprawę z zaproponowanego powyżej i bardzo potrzebnego odróżnienia, ale jednocześnie wprowadza dodatkowe, niepożądane już komplikacje. Po pierwsze, mówienie o odpowiedzialności za słowo zakłada perspektywę subiektywną (odpowiedzialność jest zawsze czyjaś i wobec kogoś), podczas gdy normy mają charakter intersubiektywny; po drugie, przypisuje ono ocenę moralną przede wszystkim nadawcy aktu, choć - jak się jeszcze okaże wymagania etyczne należy stawiać wszystkim uczestnikom komunikacji ${ }^{7}$; po trzecie wreszcie, nieco inaczej rozkłada akcenty w samej ocenie. Zachowanie mowne może przecież być nieodpowiedzialne, ale zgodne z zasadami etyki (np. ujawnienie w najlepszej intencji faktu zgodnego z prawdą, lecz mającego dla kogoś fatalne następstwa); może być ono również nieetyczne, ale odpowiedzialne - tak się dzieje np., kiedy władze zatajają przed opinią publiczną prawdę o jakimś zagrożeniu, aby uniknąć paniki. Wydaje się, że wypowiedź (nie)odpowiedzialna to przede wszystkim taka, które (nie) szkodzi/(nie) może szkodzić komuś/czemuś ze względu na (nie)umiejętność przewidywania konsekwencji; osoba odpowiedzialna kieruje się przede wszystkim pytaniem: co się stanie, jeśli zrobie (w przypadku komunikacji - powiem) $p ?^{8}$ Moralna waloryzacja wypowiedzi (podobnie jak ocena czynów) uruchamia chyba nieco inne kryteria - w etyce słowa patrzymy przede wszystkim nie na następstwa, ale na intencje - oczywiście te intencje, które znajdują wyraz w tekstach i mogą być na ich podstawie rozpoznane. Nadrzędne pytanie rządzące zachowaniem etycznym to: co chcę uzyskać, robiac (w przypadku komunikacji mówiac) p?, a ocenie poddajemy zamierzenia - także te, które z różnych powodów okazały się niemożliwe do zrealizowania. O moralnej wartości aktu nie decydują przecież realnie zachodzące po nim wydarzenia, choćby pozostawały z nim w relacji przyczynowo-skutkowej. Jeśli np. szczerze zamierzamy kogoś przeprosić, na ocenę samego aktu nie wpływa to, czy adresat przyjął przeprosiny, czy je odrzucił. Jednocześnie nawet ewidentne zło popełnione w następstwie aktu mowy, który był pozbawiony złych intencji, nie pociąga

\footnotetext{
${ }^{7}$ Sformułowanie odpowiedzialność za słowo nie wyklucza oczywiście rozumienia nakładającego pewne zobowiązania moralne np. na odbiorcę komunikatu (odpowiedzialność za słowo, które się przyjmuje), ale taka interpretacja pojawia się niezwykle rzadko, o ile w ogóle.

${ }^{8}$ Problem odpowiedzialności za słowo wymaga jeszcze niewątpliwie dalszej refleksji. Być może należałoby tu mówić o różnych koncepcjach. Do myślenia daje bowiem fakt, że z odpowiedzialnością za słowo łączy się niekiedy także działania neutralne aksjologicznie. Nie uważamy za nieetyczne np. wielosłowia (o ile nie ma za zadanie np. przesłonięcia czegoś istotnego, co nadawca chce ukryć), które jest czasem traktowane jako przejaw braku odpowiedzialności za słowo.
} 
za sobą potępienia samej wypowiedzi, ponieważ należy ono do zupełnie innego porządku - porządku decyzji sprawcy.

Wskazane wyżej tezy leżące u podstaw etyki słowa dotyczą komunikacji w ogóle. Mówienie o etycznym wymiarze wypowiedzi artystycznych wymaga przyjęcia jeszcze kilku dodatkowych założeń związanych ze szczególnym statusem tekstów literackich. Założenia te można sformułować w następujący sposób:

1. Wypowiedź artystyczna nie jest czymś istotowo różnym niż wytwory języka ogólnego i pozostałych jego odmian, przeciwnie - rządzi się ona zasadniczo tymi samymi prawami, choć jest odmiennie od nich skonstruowana, ma inaczej rozłożone akcenty i pełni inne funkcje.

2. Utwór literacki, podobnie jak wszelkie inne wypowiedzi, stanowi jeden z elementów aktu mowy albo - dużo częściej - sygnalizuje cały zespół hierarchicznie zorganizowanych aktów ${ }^{9}$.

3. Akty dokonywane w dziele literackim są wprawdzie wpisane w skomplikowany, hierarchiczny układ instancji nadawczo-odbiorczych i często wyrażane w sposób niestandardowy, można je jednak zinterpretować na odpowiednim poziomie nadawczo-odbiorczym i ostatecznie wpisać w nadrzędny makroakt, który wszystkie te akty współtworzą i który rozgrywa się między prawdziwym autorem tekstu a jego realnym, konkretnym odbiorcą. U podstaw etycznej refleksji na temat dzieła literackiego leży zatem przekonanie, że niezależnie od swego fikcjonalnego charakteru - istnieje ono również i oddziałuje w pewnej rzeczywistej relacji międzyosobowej, że jego powstaniu towarzyszą określone intencje nadawcy, a jego lektura i interpretacja pociąga za sobą konkretne skutki ${ }^{10}$

Sprawa intencji i skutków aktów obecnych w komunikacji literackiej wymaga głębszej refleksji. Wielu badaczy podziela zdanie Richarda Ohmanna, że „dzieła literackie są to wypowiedzi, w których zwykłe reguły illokucyjne

\footnotetext{
9 Na ten temat zob.: R. OHMAnN, Akty mowy a definicja literatury, przeł. B. Kowalik, W. Krajka, „Pamiętnik Literacki” 71(1980), nr 2, s. 249-267; TEGOŻ, Literatura jako akt, przeł. B. Kowalik, W. Krajka, „Pamiętnik Literacki” 71(1980), nr 2, s. 269-286; A. KALBARCZYK, Liryka wśród aktów mowy. Próba aplikacji językoznawczych teorii pragmatycznych do analizy tekstu lirycznego, Lublin: Wydawnictwo UMCS 2013 (tu również nowsza literatura przedmiotu). Przy okazji trzeba zauważyć, że często stosowane w tych pracach wyrażenie typu: tekst jest aktem czy tekst składa się z aktów jest nieprecyzyjne, ponieważ akt i tekst to zjawiska z innych poziomów, przy czym tekst jest - jak już wspominałam - jednym z komponentów aktu. Istotę sprawy znacznie lepiej oddaje więc formuła odwrotna: akt składa się (m.in) z tekstu.

${ }^{10}$ Oczywiście mowa tu o skutkach w tym sensie, o jakim pisał John L. Austin, a zatem nie o efektach w świecie realnym, lecz mentalnych i/lub dotyczących relacji społecznych.
} 
zostały zawieszone, są to akty pozbawione swych normalnych następstw"11. $\mathrm{Z}$ taką tezą trudno się całkowicie zgodzić. Po pierwsze, akty wykonywane $\mathrm{w}$ świecie przedstawionym $\mathrm{w}$ tekście mają określone skutki w obrębie tego świata (np. w komunikacji między bohaterami, którzy mogą się przecież zapraszać, pytać, komplementować itp. oraz - jako odbiorcy - czuć się zaproszeni, zapytani, skomplementowani itp.); po drugie, trzeba pamiętać, że rozważamy nie to, co zostało czy jest powiedziane (i czemu można przypisać kwalifikację prawdy/fałszu/fikcji), ale to, po co (z jaką intencją) się mówi i jakie skutki wywołuje ta wypowiedź. Reguły illokucyjne nie są więc w tekstach literackich zawieszone tak samo jak wówczas, gdy np. udajemy jakiś akt, czyli bierzemy w nawias illokucję, nie przypisując wypowiedzi określonych przewidzianych dla niej intencji; makroakt, który dokonuje się poprzez percepcję dzieła, nie jest czynnością wykonywaną „na niby”, choć fikcyjne mogą być składające się nań akty.

Etyczna ocena wypowiedzi literackiej wymaga zatem dokonania jej całościowej interpretacji, prowadzącej do uchwycenia głównej intencji wyrażanej w konstytuowanym przezeń nadrzędnym akcie nadawczo-odbiorczym, który dokonuje się między realnymi osobami, w określonych okolicznościach, w konkretnym czasie i miejscu (czy raczej - łączy konkretne punkty w czasoprzestrzeni). Waloryzacja ta może być dokonana zarówno przez samych uczestników aktu, niejako $\mathrm{z}$ wewnątrz, jak i przez jego zewnętrznego obserwatora (np. badacza). W relacji autor-czytelnik (odbiorca) dzieła wartościowanie ma charakter niesymetryczny: to zwykle odbiorca ocenia działania nadawcy. Choć w procesie odbioru literatury istotną rolę odgrywają również: rzeczywista postać autora, jego poglądy i sposób postępowania w realnym życiu, dokonywana przez czytelnika ocena nie musi obejmować i najczęściej nie obejmuje wszystkich tych aspektów - przeciwnie, dotyczy ona zwykle „autora domyślnego"12, który jawi się odbiorcy poprzez tekst, ukazując swój fragmentaryczny, zwykle w pewnym stopniu przekształcony, wykreowany obraz. Można również oceniać (nie)etyczność utworów anonimowych, pseudonimowanych czy napisanych przez autorów całkowicie nieznanych czytelnikom.

Autor ma zdecydowanie mniej okazji do refleksji na temat postawy odbiorcy - dzieje się tak tylko wówczas, gdy obaj partnerzy komunikacji literackiej żyją mniej więcej $\mathrm{w}$ tym samym czasie, a do autora dotrze jakieś

11 R. OHMANN, Literatura jako akt, s. 280.

12 Określeniem ,autor domyślny” posługuje się w swoich analizach etyki komunikacji literackiej Martha Nussbaum (zob. M. Nussbaum, Czytać, aby zyć, przeł. A. Bielik-Robson, „Teksty Drugie” 2002, z. 1-2, s. 7-24). 
świadectwo recepcji (np. recenzja, omówienie, adaptacja itp.) ${ }^{13}$. Mamy więc do czynienia $\mathrm{z}$ pewną asymetrią: postępowanie nadawcy podlega ocenie moralnej regularnie, ale tylko w pewnym zakresie, który da się przewidzieć, a nawet zaprojektować; wskutek tego ocena dotyka w pierwszej kolejności konstruktu nazwanego powyżej ,,autorem domyślnym”, natomiast autora prawdziwego, który naprawdę odpowiada za kształt swego dzieła, w tym także za kreację samego autora domyślnego, dosięga jedynie pośrednio. Z kolei recepcja tekstu bywa oceniana przez jego autora w omawianej perspektywie tylko wyjątkowo, ale za to przedmiot tej refleksji stanowi określony akt lekturowy konkretnego odbiorcy, a nie odbiorcy zaprojektowanego czy wirtualnego.

Nieco inna asymetria pomiędzy pozycją nadawcy i odbiorcy jest widoczna we współczesnej refleksji z zakresu etyki słowa. Znamienne, że w opracowaniach omawiających etyczny wymiar komunikacji w ogóle, w tym szczególnie dyskursu publicznego, akcentuje się przede wszystkim powinności nadawcy, podczas gdy w sferze komunikacji literackiej najczęściej mowa o normach, którymi ma się kierować odbiorca. Właśnie etyka lektury czy interpretacji, a nie etyka twórczości, stoi w centrum prac Jacques'a Derridy, Paula de Mana, Johna Hillisa Millera czy Dereka Attridge'a i innych uczonych współtworzących „zwrot etyczny” w badaniach literackich ${ }^{14}$. Wydaje się, że potrzeba tu swego rodzaju sprawiedliwości - od zobowiązań natury moralnej nie wypada uwalniać ani odbiorcy tekstów nieliterackich, ani też nadawcy literackich. Każda z wymienionych ról wiąże się oczywiście ze swoistymi, nieporównywalnymi do innych powinnościami, ale to już inna sprawa, do której przyjdzie mi zresztą jeszcze powrócić.

Choć w centrum komunikacji literackiej znajduje się relacja nadawcy i odbiorcy ${ }^{15}$ i najczęściej rozważa się akt, w który zaangażowane są te dwie osoby, komunikacja ta obejmuje również inne relacje, które także mają wymiar aksjologiczny. W ścisłym sensie należałoby więc mówić - i czasem się mówi ${ }^{16}$ - o całej siatce zobowiązań poszczególnych uczestników różnych

${ }^{13}$ Ta sytuacja powoli się zmienia i będzie zmieniać nadal ze względu na coraz bliższy kontakt autorów z ich czytelnikami, np. poprzez media społecznościowe.

${ }^{14}$ Określenia „,zwrot etyczny” użył jako pierwszy Michał Paweł Markowski, który zauważył, że „dla lat dziewięćdziesiątych najmodniejszym językiem anglosaskiego literary criticism wydaje się język etyki” (M.P. MARKOWSKI, Zwrot etyczny w badaniach literackich, „Pamiętnik Literacki” 2000, nr 1, s. 240). Zob. też A. BURZYŃSKA, Krajobraz po dekonstrukcji (Cz. 1), „Ruch Literacki” 1995, z. 1, s. 73-91.

15 Podobnie ujmuje tę kwestię Martha Nussbaum (Czytać, aby żyć).

${ }^{16}$ Na szczególną uwagę zasługują tu wypowiedzi samych twórców, którzy niejednokrotnie podkreślali możliwość, a czasem nawet konieczność wartościowania literatury w perspektywie 
aktów mieszczących się w obszarze komunikacji literackiej wobec innych jej uczestników lub elementów ${ }^{17}$, czyli o:

1. powinnościach autora:

- wobec odbiorcy,

- wobec samego dzieła,

- wobec języka, w jakim został napisany tekst,

- wobec tego, co przedstawione;

- wobec innych autorów,

- wobec innych osób zaangażowanych w powstanie, upowszechnianie i dystrybucję tekstów literackich;

2. powinnościach odbiorcy:

- wobec autora,

- wobec dzieła;

3. powinnościach innych osób zaangażowanych w komunikację literacką, m.in.: krytyków, recenzentów, edytorów, tłumaczy, inscenizatorów, badaczy, popularyzatorów i menadżerów literatury ${ }^{18}$ :

- wobec autora,

- wobec odbiorcy,

- wobec dzieła.

\section{NORMY ETYCZNE W KOMUNIKACJI LITERACKIEJ}

Wskazana powyżej wielość i wielorakość relacji obecnych w komunikacji literackiej pociąga za sobą konieczność sformułowania norm dla każdej z wy-

dobra i zła. Por. np. fragment Ars poetica Romana Brandstaettera: „Początkiem i źródłem dobrego pisania / Jest moralność. / Poetyka wyrasta z etyki / Jak winnica z czerwonej ziemi" (R. BRANDSTAETTER, Wiersze i poematy, Kraków: Wydawnictwo M 2003, s. 8).

${ }^{17}$ Wprawdzie ocenie podlegaja jedynie działania człowieka, ale punktem odniesienia dla tych działań mogą być także byty nieosobowe. W związku z możliwościami rozszerzenia zobowiązań etycznych zob. M. HoŁY-ŁUCZAJ, Rzeczy użytkowe i kwestia ekstensjonizmu zobowiazań etycznych - wybrane problemy, „Studia Humanistyczne AGH” 17(2018), 1, s. 85-99 (w artykule można znaleźć bogatą bibliografię prac poświęconych temu zagadnieniu i omówienie głównych stanowisk w tej kwestii).

${ }^{18}$ Wartości i normy obowiązujące w niektórych z wymienionych grup były już przedmiotem opisu, zob. np.: M. DĄBrowsKI, Projekt krytyki etycznej. Studia i szkice literackie, Kraków: Universitas 2005; M. SAGANIAK, Editore - traditore? Modernizacja pisowni wobec architektoniki stowa wypowiedzi artystycznej, „Sztuka Edycji. Studia Tekstologiczne i Edytorskie" 2011, nr 1, s. 13-19. Etyczne dylematy związane z tłumaczeniami omawia Agata Brajerska-Mazur w artykule Lojalność ttumacza, „Roczniki Humanistyczne” 67(2019), z. 6, s. 29-49. 
różnionych klas uczestników. Jak już wspomniałam, w poszukiwaniu zasad etycznej komunikacji w ogóle najczęściej koncentrowano uwagę na akcie nadawczo-odbiorczym. Jadwiga Puzynina i Anna Pajdzińska, autorki klasycznego już artykułu Etyka słowa, zaproponowały następujące normy etycznej komunikacji:

1. dotyczące nadawcy:

- nie krzywdzić drugiego człowieka ani też grup społecznych słowem wrogim, poniżającym, raniącym;

- nie okłamywać innych, nie manipulować nimi za pomocą półprawd, pochlebstwa, demagogii, szantażu;

- mówić tak, by partnerzy czuli się bezpiecznie i mieli świadomość akceptacji;

- mówić to, co się uważa za prawdę, chyba że przemilczenie lub nawet kłamstwo są uzasadnione dobrem innych;

- mówić tak, by nie utrudniać partnerowi rozumienia i nie denerwować go brakiem poprawności lub snobizmem językowym;

2. dotyczące odbiorcy:

- nie zrywać dialogu, nie zamykać się na słowo innych, nie przyjmować go z uprzedzeniami;

- nie być naiwnym w odbiorze komunikatów, zdawać sobie sprawę z możliwości okłamywania i manipulacji; wysłuchiwać innych z dobrą wolą, choć bez naiwności, starając się rozumieć ich racje ${ }^{19}$.

Normy te mają charakter ogólny i mogą, a nawet powinny zostać adaptowane do poszczególnych sfer komunikacji. Próbą dostosowania ich do specyfiki wypowiedzi artystycznej jest propozycja przedstawiona we wspominanym już artykule Anny Kozłowskiej Etyczny wymiar komunikacji literackiej w perspektywie jezykoznawstwa, w którym pojawiają się następujące zasady:

1. dla nadawcy:

- pisz o tym, co uważasz za ważne i/lub pożyteczne dla odbiorcy; w wyborze i sposobie prezentacji tematu oraz w sposobie konstruowania tekstu podążaj za tym, co wydaje ci się właściwe, a nie za wymaganiami rynku czy modą;

- nie szokuj odbiorcy i nie prowokuj go dla samej prowokacji (chyba że chcesz tym sposobem uświadomić mu coś istotnego);

\footnotetext{
${ }^{19}$ Zob. J. PUZYNinA, A. PAJDZIŃSKA, Etyka stowa, w: O zagrożeniach i bogactwie polszczyzny, (Forum Kultury Słowa), red. J. Miodek, Wrocław: Towarzystwo Przyjaciół Polonistyki Wrocławskiej 1996, s. 42.
} 
- szanuj racje odbiorcy, nie manipuluj nimi, nie narzucaj swoich sądów jako jedynie słusznych, ale też nie schlebiaj niczyim przekonaniom;

- nie blokuj ani nie zrywaj kontaktu - uczyń swój tekst możliwym do zrozumienia;

2. dla odbiorcy:

- dąż do zrozumienia ze skupieniem i uwagą, zastosuj taką miarę wysiłku interpretacyjnego, która jest adekwatna do twoich celów;

- staraj się uzyskać kompetencje umożliwiające skuteczność twojego działania: językowe, związane $\mathrm{z}$ wiedzą o epoce, autorze, świecie przedstawionym, kontekstach interpretacyjnych itp.;

- pozbądź się uprzedzeń wobec nadawcy; okaż mu zaufanie;

- nie blokuj ani nie zrywaj kontaktu - tak długo, jak tylko możesz, postępuj zgodnie z założeniem, że tekst jest spójny, sensowny, ważny i/lub pożyteczny ${ }^{20}$.

Uwzględnienie również innych relacji komunikacyjnych (wymienionych powyżej w części 1.) pozwoliłoby przyjąć następujący, rozszerzony i nieco doprecyzowany zestaw norm etycznej komunikacji literackiej:

1. dla nadawcy:

- wobec odbiorcy:

- staraj się pisać o tym, co uważasz za ważne i/lub pożyteczne dla odbiorcy; w wyborze i sposobie prezentacji tematu oraz w sposobie konstruowania tekstu podążaj za tym, co wydaje ci się właściwe, a nie za wymaganiami rynku czy modą;

- respektuj świat wartości wyznawanych przez odbiorcę; staraj się nie naruszać tych wartości i nie prowokować odbiorcy dla samej prowokacji (chyba że chcesz tym sposobem uświadomić mu coś istotnego);

- szanuj racje odbiorcy, nie manipuluj nimi, nie narzucaj swoich sądów jako jedynie słusznych, ale też nie schlebiaj niczyim przekonaniom;

- staraj się podtrzymywać kontakt;

- wobec dzieła:

- bądź odpowiedzialny za to, co i w jaki sposób mówisz; dbaj o estetyczne walory tekstu ${ }^{21}$;

\footnotetext{
${ }^{20}$ Zob. A. KozŁowsKa, Etyczny wymiar komunikacji literackiej, s. 56-57.

${ }^{21}$ Wydaje się, że - inaczej niż w przypadku tekstów, które nie pełnią funkcji artystycznych - estetyczne walory wypowiedzi literackiej (najczęściej utożsamiane z jej pięknem, choć nie tylko) to jeden $\mathrm{z}$ elementów składających się na pozytywną jej ocenę, także w sensie moralnym.
} 
- uczyń swój tekst możliwym do zrozumienia;

- wobec języka, w jakim został napisany tekst:

- staraj się wzbogacić i udoskonalić język, którym się posługujesz;

- wobec tego, co przedstawiane:

- w kreowaniu elementów świata przedstawionego kieruj się dobrem ich ewentualnych pierwowzorów;

- wobec innych autorów:

- respektuj prawo innych autorów do ich własności intelektualnej - szanuj cudze pomysły i dokonania;

- wobec innych osób zaangażowanych w powstanie, upowszechnianie i dystrybucję tekstów literackich:

- w miarę możliwości i potrzeb bierz pod uwagę głosy i rady innych osób, szanuj ich pracę;

- jeśli korzystasz z pomocy innych osób w przygotowaniu i/lub ogłaszaniu tekstu, oddaj im sprawiedliwość w sposób adekwatny do ich wkładu;

2. dla odbiorcy:

- wobec autora:

- pozbądź się uprzedzeń wobec autora; okaż mu zaufanie;

- staraj się nie blokować ani nie zrywać kontaktu;

- wobec dzieła:

- dąż do zrozumienia ze skupieniem i uwagą, stosuj taką miarę wysiłku interpretacyjnego, która jest adekwatna do twoich celów;

- staraj się uzyskać i wykorzystywać kompetencje umożliwiające efektywność twoich działań interpretacyjnych: językowe, związane z wiedzą o epoce, autorze dzieła, świecie przedstawionym, kontekstach itp.;

- tak długo, jak tylko możesz, postępuj zgodnie z założeniem, że tekst jest spójny, sensowny, ważny i/lub pożyteczny.

Zaleceń dla innych osób biorących udział w komunikacji literackiej chyba jeszcze nie proponowano. W moim pojęciu podstawowy „kodeks” jej uczestnika mógłby wyglądać następująco:

- wobec autora:

- staraj się zrozumieć intencje autora i przekazywać/oddawać/objaśniać je możliwie dokładnie;

- w swoich działaniach kieruj się przede wszystkim dobrem autora, a nie chęcią wypromowania siebie lub dążeniem do większego zysku² ${ }^{22}$;

\footnotetext{
${ }^{22}$ Warto dodać, że pewna część sytuacji, do których odnosi się ta zasada, jest regulowana przepisami prawa autorskiego.
} 
- wobec odbiorcy:

- poprzez swoje działania staraj się umożliwić i/lub ułatwić kontakt odbiorcy z tekstem i pośrednio z jego autorem;

- wobec dzieła:

- stosuj taką miarę wysiłku, która jest odpowiednia do twoich celów;

- staraj się uzyskać i wykorzystywać kompetencje umożliwiające skuteczność twojego działania.

Zaproponowany zestaw reguł ma oczywiście charakter otwarty i wymaga dalszych doprecyzowań, a prawdopodobnie także uzupełnień. Należałoby również przemyśleć sposób formułowania norm, ponieważ - niezależnie od samej treści - ujawnia on i sugeruje odbiorcy pewne przekonania na temat ich natury. W dotychczasowych pracach zasady etyczne były wyrażane zarówno pozytywnie, jako rodzaj polecenia bądź rady, jak i negatywnie, jako zakazy (Puzynina i Pajdzińska mówią o normach „na tak” i „na nie”). Wydaje się, że ten pierwszy rodzaj wysłowienia zdecydowanie lepiej odpowiada specyfice etycznej oceny wypowiedzi literackich, w której chodzi nie tyle o wskazywanie nadużyć (trudnych zresztą do jednoznacznego uchwycenia), ile o zachęcanie do budowania kontaktu respektującego prawo każdego uczestnika komunikacji do ,życzliwego dialogu” ${ }^{23}$. Zasada, że propagowanie dobra powinno mieć pierwszeństwo przed piętnowaniem zła, dotyczy etyki słowa we wszelkich możliwych sferach komunikacji; w obszarach innych niż literatura dużo łatwiej jednak precyzyjnie wskazać, na czym polega zarówno przestrzeganie norm, jak i ich naruszanie. Tymczasem etyczna komunikacja literacka jest raczej pewnym ideałem niż jasno zdefiniowanym i wyraźnie odróżniającym się od innych typem zachowania; granice tego, co w wypowiedziach artystycznych właściwe i niewłaściwe, pozostają do pewnego stopnia rozmyte i subiektywne, a niedookreśloność intencji oraz subtelność form ich wyrażania stanowią specyficzną własność tego typu komunikacji. Wskazane cechy to oczywiście niemała trudność dla etycznej oceny wypowiedzi literackiej. Są one jednak niezbywalnym wyznacznikiem takiej komunikacji i warto je podkreślać poprzez stosowane w normach etycznych wyrażenia. Dlatego właśnie formuły o obniżonej kategoryczności, zwracające uwagę na proces dążenia do etycznego komunikowania się, a nie na sam efekt, formuły

${ }^{23}$ O prawie tym wspominała Jadwiga Puzynina w artykule odróżniającym etykę komunikacji od tzw. mowy nienawiści, czyli zachowań mownych stygmatyzujących czy wykluczających określone grupy i/lub ich członków (zob. J. PuZYNINA, Mowa nienawiści - a etyka słowa, w: Barwy stów. Studia lingwistyczno-kulturowe, red. D. Filar, P. Krzyżanowski, Lublin: Wydawnictwo UMCS 2017, s. 663-670). 
typu: staraj się o..., daż do..., kieruj się czymś... wydają się w tym wypadku lepsze niż: rób coś, a zwłaszcza nie rób czegoś...

\section{SPOSÓB OCENIANIA WYPOWIEDZI LITERACKICH}

Wszystkie normy obecne w komunikacji opierają się na określonych fundamentach etycznych, a właściwie - na założeniach różnych systemów etycznych i w związku z tym są do nich zrelatywizowane. Najczęściej autorzy prac z zakresu etyki słowa odwołują się do bardzo ogólnych zasad - szacunku dla partnera, czyli poszanowania jego godności, autonomiczności (suwerenności ${ }^{24}$ i uwzględnienia wymiaru osobowego, oraz do uznania wartości prawdy. Nie inaczej powinno być i w przypadku etyki literatury, która ze względu na swoją specyfikę musi mieć charakter możliwie uniwersalny. Trzeba jednak pamiętać, że normy etyczne są zmienne w czasie i uwarunkowane społecznie; reguły, według których oceniana jest komunikacja, także literacka, powinny być zatem odnoszone do epoki i środowiska, w jakich powstało dzieło. Ponieważ komunikacja literacka dokonuje się ponad epokami i grupami społecznymi, sytuacje, w których do oceny aktów komunikacji stosuje się niewłaściwe (najczęściej zaczerpnięte $\mathrm{z}$ praktyki komunikacyjnej oceniającego, a więc anachroniczne) kryteria, są w praktyce chyba nieuniknione; w postępowaniu o bardziej zdyscyplinowanym charakterze nie sposób jednak ganić np. pisarzy ukształtowanych w kulcie imitatio za przywłaszczanie sobie fragmentów tekstów innych autorów ani odbiorców XIX-wiecznych za waloryzowanie tekstów dawnych zgodnie z kryteriami właściwymi ich czasom, skoro reguły piętnujące takie zachowania ukształtowały się w epokach późniejszych. Zanim przystąpi się do wartościowania konkretnego aktu komunikacji literackiej, należałoby zatem zrekonstruować zespół norm etycznych, które odpowiadaja okolicznościom jego powstania i funkcjonowania, i przykładać do niego właściwe miary. Niestety, ponieważ wciąż brak opracowań poświęconych etyce mowy minionych epok, na razie jesteśmy skazani częściowo na rozpoznania intuicyjne, oparte z konieczności na doświadczeniach współczesnych, a częściowo - na próby cząstkowego rekonstruowania dawnych norm etyki słowa

\footnotetext{
${ }^{24}$ Anna Cegieła, odwołując się do tej zasady, formułuje ją następująco: „Drugi, także ten obcy, jest takim samym człowiekiem jak ja i ma te same prawa" (A. CEGIEŁA, Stowa i ludzie: wprowadzenie do etyki stowa, Warszawa: Dom Wydawniczy Elipsa 2014, s. 59). Por. też A. Markowski, J. PuZYnina, Kultura języka, w: Wspótczesny język polski, red. J. Bartmiński, Lublin: Wydawnictwo UMCS 2001, s. 52.
} 
na podstawie ogólniejszej wiedzy o dawnej krytyce literackiej, publicystyce itp. Pewne obserwacje, choć niedotyczące stricte oceny komunikacji, ale działania w ogóle, można znaleźć w pracach historyków filozofii, z tym że one mają zwykle charakter teoretyczny i omawiaja koncepcje etyczne, podczas gdy tu przydałyby się przede wszystkim wskazówki praktyczne.

Potrzeba praktycznych rozstrzygnięć jawi się jako szczególnie istotna w sytuacji oceniania konkretnego aktu mowy. Skoro w centrum etyki literatury stoją intencje, podstawowym warunkiem i punktem wyjścia takiej oceny powinno być właściwe ich odczytanie. Obarczone jest ono oczywiście ryzykiem niezrozumienia, w przypadku dzieła artystycznego zwielokrotnionym ze względu na właściwą mu wieloznaczność i niebezpośredniość, która dotyka zarówno samych relacji osobowych, jak i sposobu wyrażania intencji komunikacyjnych. Uchwycenie tych ostatnich nie jest jednak dla filologii zadaniem nowym ani nadmiernie kłopotliwym metodologicznie - pragmatyka wypracowała już przecież pewne narzędzia opisu komunikacji nie wprost i ciągle poszukuje coraz bardziej adekwatnych metod interpretowania i eksplikowania autorskich zamierzeń oraz mechanizmów ich sygnalizowania. Wydaje się zatem, że najtrudniejszy etap waloryzacji stanowi nie samo rozpoznanie intencji, ale zestawienie ich z obowiązującymi w danym czasie i środowisku standardami etycznymi, które - jak już wspomniałam - dla większości epok i sfer komunikacji nie zostały jeszcze scharakteryzowane. Ich sformułowanie pozostaje więc jednym z głównych zadań etyki słowa na najbliższe lata.

\section{BIBLIOGRAFIA}

BRAJERSKA-MAZuR A.: Lojalność tłumacza, „Roczniki Humanistyczne” 67(2019), z. 6, s. 29-49. BRANDSTAETTER R.: Wiersze i poematy, Kraków: Wydawnictwo M 2003.

BURZYŃSKA A.: Krajobraz po dekonstrukcji (Cz. 1), „Ruch Literacki” 1995, z. 1, s. 73-91.

CegreŁA A.: Słowa i ludzie: wprowadzenie do etyki słowa, Warszawa: Dom Wydawniczy Elipsa 2014.

DĄBRowski M.: Projekt krytyki etycznej. Studia i szkice literackie, Kraków: Universitas 2005.

HOŁY-ŁUCZAJ M.: Rzeczy użytkowe i kwestia ekstensjonizmu zobowiązań etycznych - wybrane problemy, „Studia Humanistyczne AGH” 17(2018), 1, s. 85-99.

KALBARCZYK A.: Liryka wśród aktów mowy. Próba aplikacji językoznawczych teorii pragmatycznych do analizy tekstu lirycznego, Lublin: Wydawnictwo UMCS 2013.

KoZŁOwSKA A.: Etyczny wymiar komunikacji literackiej w perspektywie językoznawstwa, w: Ku rzeczom niebłahym, red. J. Chojak, Z. Zaron, Warszawa: BEL Studio 2018, s. 49-59.

MARKowsKi A., PuZYNina J.: Kultura języka, w: Współczesny język polski, red. J. Bartmiński, Lublin: Wydawnictwo UMCS 2001, s. 49-71.

MARKOwSKI M.P.: Zwrot etyczny w badaniach literackich, „Pamiętnik Literacki” 2000, nr 1(91), s. $239-244$. 
Nussbaum M.: Czytać, aby żyć, przeł. A. Bielik-Robson, „Teksty Drugie” 2002, z. 1-2, s. 7-24.

OHMAnN R.: Akty mowy a definicja literatury, przeł. B. Kowalik, W. Krajka, „Pamiętnik Literacki” 71(1980), nr 2, s. 249-267.

OHMAnN R.: Literatura jako akt, przeł. B. Kowalik, W. Krajka, „Pamiętnik Literacki” 71(1980), nr 2, s. 269-286.

PUZYNINA J.: Dlaczego bronię kultury słowa?, „Poradnik Językowy” 2014, nr 5, s. 7-15.

PuZYNinA J.: Mowa nienawiści - a etyka słowa, w: Barwy słów. Studia lingwistyczno-kulturowe, red. D. Filar, P. Krzyżanowski, Lublin: Wydawnictwo UMCS 2017, s. 663-670.

PuZYNina J., PAJDZIŃSKA A.: Etyka słowa, w: O zagrożeniach i bogactwie polszczyzny, (Forum Kultury Słowa), red. J. Miodek, Wrocław: Towarzystwo Przyjaciół Polonistyki Wrocławskiej 1996, s. 35-45.

WALCZAK B.: Aksjologia a językoznawstwo, w: Wartości i wartościowanie w badaniach nad językiem, red. M. Karwatowska, A. Siwiec, Chełm: Wydawnictwo Perfekta info 2012, s. $20-29$.

ZGóŁKA T.: Język wśród wartości, Poznań: Wydawnictwo Poznańskie 1988.

\title{
JESZCZE O PODSTAWACH ETYKI SŁOWA W KOMUNIKACJI LITERACKIEJ
}

\author{
St res z c z e i e
}

W artykule omówiono etyczną koncepcję komunikacji literackiej widzianą z perspektywy lingwistycznej. Zidentyfikowano założenia, które są niezbędne do etycznej oceny komunikacji literackiej i stanowią jej teoretyczne podstawy. W artykule zaproponowano również kodeks uczestnika komunikacji literackiej - zachowania wobec autora, odbiorcy i innych osób zaangażowanych w komunikację literacką.

Słowa kluczowe: etyka; komunikacja literacka; komunikacja językowa; ocena etyczna.

\section{AGAIN ON FUNDAMENTALS OF THE ETHICS \\ IN THE LITERARY COMMUNICATION}

S u m m a r y

The paper discusses the ethical concept of the literary communication seen from the linguistic point of view. It attempts to identify assumptions that are necessary to validate the ethical assessment of the literary communication and that constitute theoretical fundamentals of this concept.

Some ethical rules for an author, a recipient and other persons involved in the literary communication have been also proposed in the article.

Key words: ethics; literary communication; communication linguistic; validate. 